\title{
Effect of tea saponins on milk performance, milk fatty acids, and immune function in dairy cow
}

\author{
B. Wang, ${ }^{*} \dagger$ Y. Tu, ${ }^{*}$ S. P. Zhao,† Y. H. Hao,† J. X. Liu,† F. H. Liu,† B. H. Xiong, $\S^{1}$ and L. S. Jiang ${ }^{1}$ \\ ${ }^{*}$ Feed Research Institute, Chinese Academy of Agricultural Sciences, Beijing 100081, China \\ †Beijing Key Laboratory for Dairy Cow Nutrition, College of Animal Science and Technology, Beijing University of Agriculture, Beijing 102206, \\ China \\ łInstitute of Dairy Science, MoE Key Laboratory of Molecular Animal Nutrition, College of Animal Sciences, Zhejiang University, \\ Hangzhou 310058, China \\ §State Key Laboratory of Animal Nutrition, Institute of Animal Science, Chinese Academy of Agricultural Sciences, Beijing, 100193, China
}

\section{ABSTRACT}

This study investigated the effects of tea saponins (TSP) on milk performance, milk fatty acids, and blood immune function in dairy cows. A total of 20 earlylactation Holstein cows (days in milk $=66.4 \pm 16.8 \mathrm{~d}$; parity $=1.75 \pm 0.91 ;$ and milk yield $=36.3 \pm 7.32 \mathrm{~kg} / \mathrm{d}$; mean \pm standard deviation) were randomly divided into 4 homogeneous treatment groups, with TSP added at $0,20,30$, and $40 \mathrm{~g} / \mathrm{d}$ per head, respectively. All cows had 2 wk of adaptation and 6 wk of treatments. Feed, milk, and blood were sampled and analyzed weekly. At the end of the experimental period (wk 6), the dry matter intake and yields of energy-corrected milk, milk, and milk protein, fat, and lactose in the cows fed TSP showed a quadratic response, with the lowest values in cows fed TSP at $40 \mathrm{~g} / \mathrm{d}$. The milk fat content of cows fed TSP increased linearly. Significant interactions for treatment by week were found in milk C16:1 cis-9 and C18:1 cis-9, with the highest values at wk 2,3 , and 4 in the cows fed TSP at $40 \mathrm{~g} / \mathrm{d}$. The levels declined quickly after 4 wk of feeding to values similar to those for other TSP treatments and the control at wk 5 and 6. Plasma malondialdehyde concentration decreased as the supplement level of TSP increased. The concentration of superoxide dismutase increased as the supplement level of TSP increased. The plasma concentration of tumor necrosis factor- $\alpha$ increased as the supplement level of TSP increased. In summary, this study showed that an intermediate dose of TSP (20 and $30 \mathrm{~g} / \mathrm{d}$ ) had no significant effect on feed intake, but the supplementation of $40 \mathrm{~g} / \mathrm{d}$ TSP decreased feed intake, resulting in a lower milk yield. The energy-corrected milk of cows fed $40 \mathrm{~g} / \mathrm{d}$ TSP declined at first but increased after

Received December 8, 2016

Accepted May 28, 2017.

${ }^{1}$ Corresponding authors: jls@bac.edu.cn and bhxiong@iascaas.net. cn
3 wk of feeding, indicating the potential adaptation to high doses of TSP supplements in dairy cows. The supplementation of TSP could reduce oxidative stress in cows and improve the immunity of dairy cows during 6 wk of feeding.

Key words: fatty acids, immune function, milk quality, tea saponins

\section{INTRODUCTION}

Tea saponins (TSP), which mainly consist of triterpenoid saponins, have been reported to have antimicrobial effects, decrease methane emission, and alter rumen fermentation by killing protozoa and increasing microbial protein synthesis (Hu et al., 2006; Guo et al., 2008; Wang et al., 2012). The decreased methane emission accompanied by increased ruminal microbial protein synthesis might be an indicator that the rumen fermentative environment is good for animal production (Wang et al., 2012). Decreased methane emissions were reported in some trials (Wang et al., 2012), but several other studies found inconsistent results. Some studies indicated that the methane emissions could not be changed (Guyader et al., 2015; Ramírez-Restrepo et al., 2016), and others showed that the growth of lambs changed little (Mao et al., 2010) after they were fed TSP. Such mixed results indicate that more research on TSP is needed.

In addition, TSP has been shown to have antioxidant capacity as well as antifungal, antiviral, and antiinflammatory activities (Francis et al., 2002; Zhou et al., 2012; Li et al., 2015). In general, the antioxidant effect of TSP is mainly due to the reducing function of acyl and hydroxyl group of saponins, which can directly remove free radicals or inhibit the initiation of the free radical chain reaction (Guyader et al., 2015). The antifungal effect is through the invasion of microbial cell membrane structure, leading to cell membrane disintegration caused by ion loss (Wanapat et al., 2012). 
Therefore, TSP has been proposed as a potential substitute for antibiotics in animal feed (Francis et al., 2002).

In addition, ruminal acetate and butyrate (the milk fat precursor) and their proportions were reduced by increasing TSP supplementation (Guyader et al., 2017). This finding indicated that the milk fatty acid (FA) profile might be altered by TSP supplementation. However, the influence of TSP on dairy cow milk production and milk FA profile has received limited research attention. We hypothesize that milk production and milk FA profile could be changed by feeding TSP to lactating cows. Our goal was to perform a dose-response study on TSP supplementation in dairy cows and its effect on their lactation performance, milk FA profile, antioxidative status, and immune response.

\section{MATERIALS AND METHODS}

\section{Tea Saponins}

Tea saponins ( $\geq 56 \%$ purity of triterpenoid saponins) in powder form were provided by the Zhejiang Orient Tea Industry (Shaoxing, China). The proportion of CP, NDF, ether extract, and ash in TSP were 4.12, 2.78, 9.60 , and $9.88 \%$ of DM, respectively.

\section{Animals, Diets, and Experimental Design}

A total of 8 primiparous and 12 multiparous lactating Holstein dairy cows were blocked based on parity and milk production and were randomly assigned to 1 of 4 dietary groups, with 5 cows in each group (2 primiparous and 3 multiparous cows). No initial differences existed between the groups in terms of milk yield $(36.3 \pm 7.32 \mathrm{~kg} / \mathrm{d} ; P=0.88)$, DIM $(66.4 \pm 16.8 \mathrm{~d} ; P$ $=0.38)$, parity $(1.75 \pm 0.91 ; P=0.81)$, and BW (550 $\pm 30 \mathrm{~kg} ; P=0.27)$. The cows were fed the same basal diet with TSP supplementation of 0 (control), 20, 30, or $40 \mathrm{~g} / \mathrm{d}$ per head. The TSP dose for dairy cows in this study was calculated based on the predicted rumen volume and extrapolations from an in vitro study and an in vivo study in goats (Hu et al., 2006; Zhou et al., 2012). The dietary ingredients and nutrient composition of the basal TMR are presented in Table 1 . The cows were housed in individual tiestalls, with feed available for ad libitum consumption and free access to water. Feeding and milking occurred 3 times per day $(0730,1430$, and $2130 \mathrm{~h})$. The experiment lasted for 8 wk, with a 2 -wk adaption period and a 6 -wk sampling period. Animals selected in this study were provided by the Beijing Sanyuan Lvhe Dairy Farming Center (Beijing, China), and the experimental procedures were approved by the Animal Care Committee, Beijing Agriculture University (Beijing, China).

\section{Feed and Milk Sampling and Analysis}

Daily milk production and DMI were recorded for the first 3 consecutive days of each sampling week throughout the duration of the trial. Milk samples were collected on the third day of each week using milksampling devices (Waikato Milking Systems NZ Ltd., Hamilton, New Zealand). Feed and orts samples were collected once per day during the 3 consecutive days to determine the DMI. The amount of feed offered was recorded daily and adjusted to yield 5 to $10 \%$ orts; the feed intake was calculated based on the feed of-

Table 1. Ingredients and nutrient composition (\% of DM, unless otherwise specified) of basal diet used in the experiment

\begin{tabular}{|c|c|}
\hline Item & Content \\
\hline \multicolumn{2}{|l|}{ Ingredient } \\
\hline Corn silage & 46.3 \\
\hline Alfalfa hay & 6.90 \\
\hline Oat grass & 2.40 \\
\hline Ground corn & 9.88 \\
\hline Soybean meal & 5.10 \\
\hline Steam-flaked corn & 4.40 \\
\hline DDGS $^{1}$ & 4.40 \\
\hline Corn bran & 3.70 \\
\hline Extruded soybean & 3.00 \\
\hline Barley & 2.66 \\
\hline Wheat bran & 2.66 \\
\hline Sodium cyclamate & 2.40 \\
\hline Oat & 1.50 \\
\hline Canola meal & 1.07 \\
\hline Cottonseed meal & 1.07 \\
\hline Megalac $^{2}$ & 0.90 \\
\hline $\mathrm{NaHCO}_{3}$ & 0.59 \\
\hline Limestone & 0.48 \\
\hline $\mathrm{NaCl}$ & 0.27 \\
\hline MT-BOND ${ }^{3}$ & 0.02 \\
\hline Premix ${ }^{4}$ & 0.30 \\
\hline \multicolumn{2}{|c|}{ Nutrient composition $^{5}$} \\
\hline $\mathrm{CP}$ & 17.4 \\
\hline NDF & 31.1 \\
\hline $\mathrm{ADF}$ & 16.6 \\
\hline Ether extract & 5.00 \\
\hline $\mathrm{Ca}$ & 0.78 \\
\hline $\mathrm{P}$ & 0.44 \\
\hline $\mathrm{NE}_{\mathrm{L}},{ }^{6} \mathrm{Mcal} / \mathrm{kg}$ & 1.76 \\
\hline
\end{tabular}

${ }^{1}$ DDGS $=$ dried distillers grains with solubles.

${ }^{2}$ Church and Dwight Co. Inc., Princeton, NJ.

${ }^{3} \mathrm{MT}-\mathrm{BOND}=$ Matt mold rubber element (MinTech International Inc., Bloomington, IN).

${ }^{4}$ Formulated to provide (per $\mathrm{kg}$ of DM) 4,560 $\mathrm{mg}$ of $\mathrm{Cu}, 3,000 \mathrm{mg}$ of Fe, 12,100 mg of Zn, 4,590 mg of Mn, $60 \mathrm{mg}$ of Co, $200 \mathrm{mg}$ of Se, 270 $\mathrm{mg}$ of I, 10,000 IU of vitamin E, 450,000 IU of vitamin D, 2,000,000 IU of vitamin $\mathrm{A}$, and $3,000 \mathrm{mg}$ of nicotinic acid.

${ }^{5}$ Chemical composition is based on chemical analysis of the TMR as described.

${ }^{6}$ Calculated based on individual feedstuffs by the MOA (2004). 
fered and orts. The average milk production and DMI of every cow from the first 3 consecutive days for each sampling week represented the mean milk production of that week. Dietary ingredients and TMR were dried in a forced-air oven at $60^{\circ} \mathrm{C}$ for $48 \mathrm{~h}$ and then ground through a 2-mm screen (Wiley Laboratory Mill; Arthur H. Thomas Co., Philadelphia, PA). Samples were ground again through a 1-mm screen in a Cyclotec mill (Tecator 1093; Tecator AB, Höganäs, Sweden), and the ground samples were stored at $4^{\circ} \mathrm{C}$ until analysis for $\mathrm{DM}\left(105^{\circ} \mathrm{C}\right.$ for $\left.5 \mathrm{~h}\right)$, CP (method 988.05; AOAC, 1990), ash (method 942.05; AOAC, 1990), and ether extract (method 920.39; AOAC International, 2000). The NDF and ADF content were determined using an Ankom A200 apparatus (Ankom Technology, Macedon, NY) according to Van Soest et al. (1991) with heatstable amylase (Ankom Technology) and sodium sulfite (Fisher Scientific, Waltham, MA) and expressed inclusive of residual ash.

On sampling d 3 of each week, two 50-mL aliquot milk samples were collected from each cow at each milking, and these samples were composited in a 4:3:3 ratio for 3 milking times per day (Wang et al., 2014). One of the composited milk samples $(50 \mathrm{~mL})$ was collected in a sample bottle with $0.6 \mathrm{mg} / \mathrm{mL}$ potassium dichromate added as a preservative and stored at $4^{\circ} \mathrm{C}$ for further analysis of milk components including fat, protein, lactose, MUN, TS, and SCC using an automatic ultrasonic milk composition analyzer (Bentley Instruments, Chaska, MN). The other sample $(50 \mathrm{~mL})$ was stored at $-20^{\circ} \mathrm{C}$ for further analysis of milk FA composition (Pegolo et al., 2016). The FA were methylated using in situ transesterification with $0.5 \mathrm{~N}$ methanolic $\mathrm{NaOH}$ followed by $14 \%$ boron trifluoride in methanol. The FA profile was then determined using a Hewlett-Packard 6890A GC equipped with a flame-ionization detector (Hewlett-Packard, Sunnyvale, CA) and a high polar fused-silica capillary column (Chrompack CP-Sil88 Varian, Middelburg, The Netherlands; $100 \mathrm{~m}, 0.25 \mathrm{~mm}$ i.d.; film thickness $0.20 \mu \mathrm{m}$ ).

\section{Blood Sampling and Analysis}

Two blood samples $(10 \mathrm{~mL})$ were collected into lithium heparin Vacutainer tubes (Becton, Dickinson and Company, Franklin Lakes, NJ) using jugular venipuncture approximately $3 \mathrm{~h}$ post feeding on d 4 during each sampling week. Samples were immediately placed on ice until isolating plasma by centrifuging at $3,000 \times$ $g$ for $15 \mathrm{~min}$. Plasma was stored at $-20^{\circ} \mathrm{C}$ to determine the biochemical and immune metabolites. Samples were sent to the Animal Hospital of the Beijing University of Agriculture and analyzed with an Auto Analyzer 7020 instrument (Hitachi High-Technologies Corp., Tokyo, Japan) using commercial kits for each biochemical parameter. The plasma parameters from one set of plasma samples, including BUN (C013-2; Rahmatullah and Boyde, 1980), total protein (A045-3), albumin (A028-1), total cholesterol (F002-1; Mann, 1961), and triglyceride (A110-1; Delamaire and Guinard-Flament, 2006), were analyzed using blood colorimetric commercial kits (DiaSys Diagnostics Systems GmbH, Frankfurt, Germany). Globulin was calculated using the difference between total protein and albumin. The other plasma sample was used to determine the concentrations of IL-1 (H002), IL-2 (H003), IL-12 (H010), malondialdehyde (MDA; A003-1; Zhang et al., 2006), glutathione peroxidase (GSH-Px; A005; Zhang et al., 2006), and superoxide dismutase (SOD; A001-1; Zhang et al., 2006), tumor necrosis factor (TNF)- $\alpha$ (H052), and IFN- $\gamma$ (H025) with bovine ELISA kits (Nanjing Jiancheng Bioengineering Institute, Nanjing, Jiangsu, China). The plasma concentrations of IgG, IgM, and IgA were analyzed using an immunoturbidimetry assay (Thomas, 1998).

A whole blood sample was immediately analyzed for blood cell counts. A complete blood count (electrical resistance detection) for each sample (hematocrit, red blood cell, monocytes, lymphocytes, basophils, eosinophils, hemoglobin, platelet, and neutrophils) was analyzed using an automated hematology analyzer (Celltac a MEK-6450, Nihon Kohden Corp., Tokyo, Japan). Each blood analysis was performed in duplicate.

\section{Statistical Analysis}

Data were analyzed using PROC MIXED of SAS (version 9.2, SAS Institute Inc., Cary, NC) as a randomized complete block design with repeated measures; week, treatment, and interaction of treatment by week were fixed effects, and cow within diet was a random effect. The effect of week was included as a repeated measure. For the repeated measures analysis, the covariance structure with the lowest Akaike information criterion was used. Data from wk -2 was used as the covariate for statistical analysis of ECM. For the data from wk 6 (i.e., end of this experiment), orthogonal polynomial contrasts (linear and quadratic) were used to examine the responses to different doses of TSP by PROC MIXED of SAS (version 9.2, SAS Institute Inc.), with treatment as fixed effects, and cow within diet as a random effect. The results were reported as least squares means. Significance was declared at $P \leq$ 0.05; a tendency was declared at $0.05<P<0.10$. The items with significant $P$-value $(<0.05)$ for week and interaction of week by treatment are shown as figures. 


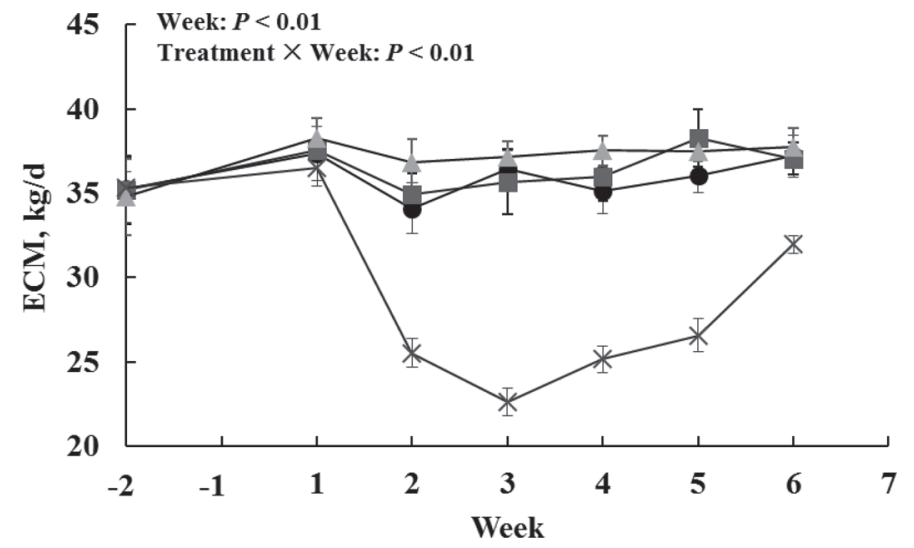

Figure 1. Change in ECM yield of lactating cows fed TMR with supplementation of 0 (control, $\bullet), 20(\mathbf{\square}), 30(\boldsymbol{\Lambda})$, and $40(\times) \mathrm{g} / \mathrm{d}$ of tea saponins. Bars indicate the standard error.

\section{RESULTS}

\section{Feed Intake and Milk Performance}

Feed intake and milk performance results at wk 6 are listed in Table 2. The DMI showed a quadratic response with increasing doses of TSP $(P=0.01)$, with cows fed $40 \mathrm{~g} / \mathrm{d}$ TSP consuming the lowest amount of DM. Yields of milk, milk fat, protein, lactose, and ECM showed a quadratic response $(P<0.05)$ in the cows receiving TSP, which was lowest for the cows fed $40 \mathrm{~g} / \mathrm{d}$ of TSP. The yield of TS decreased linearly $(P=$ 0.03 ) in the cows receiving TSP. The ECM for cows fed with increasing doses of TSP were affected by the week $(P<0.01)$ and by the interaction of treatment by week
$(P<0.01)$. The ECM of cows fed $40 \mathrm{~g} / \mathrm{d}$ TSP declined during the first $3 \mathrm{wk}$ and then rose in the last $3 \mathrm{wk}$. The ECM of cows fed $30 \mathrm{~g} / \mathrm{d}$ TSP was greater than the control at wk 2, 4, and 5 but was similar at wk 1, 3, and 6 (Figure 1). For the concentration of milk components, the milk fat concentration increased linearly $(P<0.01)$ in the cows receiving TSP. Lactose decreased linearly $(P<0.01)$ in the cows receiving TSP. However, no significant difference was found among groups for protein and TS. The MUN and SCC changed quadratically $(P$ $<0.01)$, with intermediate levels of TSP $(30 \mathrm{~g} / \mathrm{d})$ for MUN and SCC resulting in the lowest values. No difference in feed efficiency was detected among the groups.

\section{Milk Fatty Acids}

The effect of adding different levels of TSP on FA levels in raw milk at wk 6 is shown in Table 3. No differences were detected between treatments in all detected FA. However, the proportion of $\mathrm{C} 16: 1$ cis-9 and C18:1 cis-9 in total milk FA were affected by the week $(P<0.01$, except for C18:1 cis-9), and the interaction of treatment by week $(P<0.05)$. The $\mathrm{C} 16: 1$ cis-9 and C18:1 cis-9 of cows fed $40 \mathrm{~g} / \mathrm{d}$ TSP was highest at wk 2,3 , and 4 , but declined quickly after 4 wk of feeding to values similar to those of other groups at wk 5 and 6 (Figure 2).

\section{Plasma Metabolites}

The results of plasma variables at wk 6 are presented in Table 4. Plasma MDA concentration showed a qua-

Table 2. Effect of dietary addition of tea saponins for $6 \mathrm{wk}$ on DMI, milk yield, and milk composition in dairy cows

\begin{tabular}{|c|c|c|c|c|c|c|c|}
\hline \multirow[b]{2}{*}{ Item } & \multicolumn{4}{|c|}{ Tea saponins, g/d per head } & \multirow[b]{2}{*}{ SEM } & \multicolumn{2}{|c|}{$P$-value } \\
\hline & 0 & 20 & 30 & 40 & & Linear & Quadratic \\
\hline $\mathrm{DMI}, \mathrm{kg} / \mathrm{d}$ & 25.3 & 25.3 & 25.2 & 22.5 & 0.45 & $<0.01$ & 0.01 \\
\hline \multicolumn{8}{|l|}{ Yield, kg/d } \\
\hline Milk & 36.9 & 37.1 & 36.6 & 31.5 & 1.08 & $<0.01$ & 0.04 \\
\hline $\mathrm{ECM}^{1}$ & 37.1 & 37.1 & 37.8 & 32.3 & 0.90 & 0.01 & 0.01 \\
\hline Fat & 1.22 & 1.23 & 1.28 & 1.13 & 0.029 & 0.12 & 0.02 \\
\hline Protein & 1.15 & 1.13 & 1.15 & 0.92 & 0.040 & $<0.01$ & 0.03 \\
\hline Lactose & 1.89 & 1.85 & 1.81 & 1.47 & 0.063 & $<0.01$ & 0.04 \\
\hline Total solids & 4.52 & 4.23 & 4.38 & 3.67 & 0.206 & 0.03 & 0.32 \\
\hline \multicolumn{8}{|c|}{ Milk composition, \% } \\
\hline Fat & 3.35 & 3.32 & 3.50 & 3.56 & 0.050 & $<0.01$ & 0.39 \\
\hline Protein & 3.05 & 3.06 & 3.16 & 2.95 & 0.099 & 0.67 & 0.31 \\
\hline Lactose & 5.09 & 4.99 & 4.95 & 4.76 & 0.065 & $<0.01$ & 0.52 \\
\hline Total solids & 11.8 & 11.4 & 12.0 & 11.8 & 0.35 & 0.84 & 0.75 \\
\hline MUN, mg/dL & 16.6 & 15.9 & 13.1 & 16.0 & 0.48 & 0.05 & $<0.01$ \\
\hline $\mathrm{SCC}, \times 10^{3} / \mathrm{mL}$ & 47.2 & 44.0 & 42.0 & 45.2 & 0.65 & 0.02 & $<0.01$ \\
\hline Feed efficiency ${ }^{2}$ & 1.47 & 1.46 & 1.46 & 1.42 & 0.050 & 0.52 & 0.82 \\
\hline
\end{tabular}


Table 3. Effect of dietary addition of tea saponins for $6 \mathrm{wk}$ on milk individual fatty acid (FA) proportion

\begin{tabular}{|c|c|c|c|c|c|c|c|}
\hline \multirow[b]{2}{*}{ Item, ${ }^{1} \mathrm{~g} / 100 \mathrm{~g}$ of total FA } & \multicolumn{4}{|c|}{ Tea saponins, g/d per head } & \multirow[b]{2}{*}{ SEM } & \multicolumn{2}{|c|}{$P$-value } \\
\hline & 0 & 20 & 30 & 40 & & Linear & Quadratic \\
\hline SFA & 54.7 & 46.6 & 50.3 & 51.7 & 5.83 & 0.84 & 0.43 \\
\hline C6:0 & 1.59 & 1.52 & 1.58 & 1.63 & 0.12 & 0.74 & 0.64 \\
\hline C8:0 & 0.92 & 0.76 & 0.92 & 0.92 & 0.17 & 0.82 & 0.65 \\
\hline C10:0 & 2.04 & 2.02 & 1.65 & 1.87 & 0.37 & 0.60 & 0.75 \\
\hline $\mathrm{C} 12: 0$ & 2.47 & 2.38 & 1.85 & 2.20 & 0.44 & 0.51 & 0.63 \\
\hline C14:0 & 8.93 & 7.60 & 8.73 & 8.59 & 1.14 & 0.98 & 0.61 \\
\hline C16:0 & 29.4 & 24.6 & 25.6 & 25.2 & 3.26 & 0.44 & 0.52 \\
\hline C18:0 & 9.23 & 7.58 & 9.71 & 11.2 & 1.86 & 0.36 & 0.42 \\
\hline C20:0 & 0.13 & 0.11 & 0.13 & 0.14 & 0.02 & 0.58 & 0.42 \\
\hline $\mathrm{C} 22: 0$ & 0.071 & 0.077 & 0.068 & 0.071 & 0.005 & 0.66 & 0.80 \\
\hline UFA & 29.0 & 28.6 & 32.6 & 33.0 & 3.56 & 0.34 & 0.90 \\
\hline MUFA & 24.7 & 24.2 & 28.0 & 28.0 & 3.07 & 0.34 & 0.93 \\
\hline C14:1 cis-9 & 0.73 & 0.77 & 0.73 & 0.85 & 0.11 & 0.52 & 0.70 \\
\hline C16:1 cis-9 & 1.45 & 1.34 & 1.42 & 1.73 & 0.28 & 0.49 & 0.47 \\
\hline C18:1 cis-9 & 20.8 & 19.7 & 23.2 & 24.1 & 2.60 & 0.27 & 0.71 \\
\hline C18:1 trans -9 & 1.66 & 2.26 & 2.46 & 1.19 & 0.64 & 0.68 & 0.17 \\
\hline C20:1 cis-9 & 0.13 & 0.16 & 0.14 & 0.15 & 0.02 & 0.83 & 0.63 \\
\hline PUFA & 4.31 & 4.35 & 4.63 & 4.98 & 0.59 & 0.40 & 0.80 \\
\hline $\mathrm{C} 18: 2$ cis -9, cis -12 & 3.00 & 2.88 & 3.19 & 3.45 & 0.43 & 0.40 & 0.67 \\
\hline C18:2 trans -9, trans -12 & 0.66 & 0.83 & 0.68 & 0.75 & 0.15 & 0.83 & 0.75 \\
\hline $\mathrm{C} 18: 3$ cis -9 , cis -12 , cis- 15 & 0.33 & 0.33 & 0.37 & 0.40 & 0.04 & 0.26 & 0.75 \\
\hline C20:3n-6 & 0.11 & 0.09 & 0.14 & 0.12 & 0.02 & 0.37 & 0.84 \\
\hline $\mathrm{C} 20: 4 \mathrm{n}-6$ & 0.12 & 0.12 & 0.14 & 0.16 & 0.02 & 0.26 & 0.63 \\
\hline $\mathrm{C} 20: 5 n-3$ & 0.026 & 0.028 & 0.034 & 0.035 & 0.004 & 0.12 & 0.84 \\
\hline $\mathrm{C} 22: 6 \mathrm{n}-3$ & 0.027 & 0.029 & 0.033 & 0.026 & 0.004 & 0.98 & 0.34 \\
\hline MCFA & 7.02 & 6.68 & 6.00 & 6.62 & 0.99 & 0.68 & 0.64 \\
\hline LCFA & 76.8 & 68.5 & 76.9 & 78.1 & 8.05 & 0.74 & 0.56 \\
\hline Other FA & 16.2 & 24.8 & 17.1 & 15.3 & 8.85 & 0.79 & 0.56 \\
\hline
\end{tabular}

dratic response as TSP increased $(P<0.01)$, and was lowest for the cows fed $40 \mathrm{~g} / \mathrm{d}$ TSP. The concentration of SOD linearly increased as the supplemental value of TSP increased $(P<0.01)$, with the greatest value observed for cows fed $40 \mathrm{~g} / \mathrm{d}$ of TSP. No significant difference was found for the concentration of GSH-Px in cows fed with TSP. Several variables were used to evaluate immune function. The plasma concentration of IL-2 linearly increased as the supplemental value of TSP increased $(P=0.05)$, with the highest value in cows fed $40 \mathrm{~g} / \mathrm{d}$ TSP. The plasma concentration of TNF- $\alpha$ linearly increased as the supplemental value of TSP increased $(P<0.01)$. No significant treatment effect was found for the other plasma characteristics evaluated in this study. In addition, the concentration of plasma MDA and TNF- $\alpha$ were affected by the week $(P<0.01)$, and the interaction of treatment by week $(P<0.01$ for MDA, $P<0.05$ for TNF- $\alpha$ ). The plasma MDA of cows fed TSP was always lower than the control during the $6 \mathrm{wk}$, but it showed different significances. The plasma TNF- $\alpha$ of cows fed TSP was higher during the first $3 \mathrm{wk}$, but it tended to be similar to the control at wk 4 and 5 before becoming greater again at wk 6 (Figure 3).

\section{Blood Hematology}

The results of blood counts at wk 6 are shown in Table 5. The blood lymphocytes $(P=0.05)$ and eosinophils $(P=0.03)$ linearly decreased as the supplemental value of TSP increased. The red cell distribution width showed a quadratic response as the supplemental value of TSP increased $(P=0.02)$. No significant effect from diet, week, and the interaction of diet by week was found in other blood cell characteristics.

\section{DISCUSSION}

\section{Milk Synthesis}

Currently, research regarding the effect of TSP on the milk performance of dairy cows is relatively rare, and no consistent conclusions have been reached. No significant effect was observed on growth performance when TSP was added to the diet of growing lambs (Mao et al., 2010), and in steers, saponins were reported to reduce or not affect animal performance ( $\mathrm{Li}$ and Powers, 2012). In general, literature results showed no consistent reduction in animal performance when TSP was 
WANG ET AL.

Table 4. Effect of dietary addition of tea saponins for 6 wk on plasma metabolic variables in dairy cows

\begin{tabular}{|c|c|c|c|c|c|c|c|}
\hline \multirow[b]{2}{*}{ Item $^{1}$} & \multicolumn{4}{|c|}{ Tea saponins, g/d per head } & \multirow[b]{2}{*}{ SEM } & \multicolumn{2}{|c|}{$P$-value } \\
\hline & 0 & 20 & 30 & 40 & & Linear & Quadratic \\
\hline Total protein, $\mathrm{g} / \mathrm{L}$ & 68.2 & 68.0 & 69.4 & 68.0 & 1.74 & 0.92 & 0.74 \\
\hline $\mathrm{BUN}, \mathrm{mmol} / \mathrm{L}$ & 6.74 & 6.26 & 6.06 & 6.12 & 0.47 & 0.35 & 0.58 \\
\hline Triglyceride, $\mu \mathrm{mol} / \mathrm{L}$ & 32.0 & 30.0 & 32.0 & 30.0 & 2.52 & 0.73 & 1.00 \\
\hline Total cholesterol, $\mathrm{mmol} / \mathrm{L}$ & 6.28 & 6.24 & 5.93 & 5.86 & 0.38 & 0.37 & 0.97 \\
\hline Albumin, $\mathrm{g} / \mathrm{L}$ & 26.4 & 26.4 & 26.8 & 26.6 & 0.60 & 0.72 & 0.87 \\
\hline Globulin, g/L & 40.4 & 42.0 & 42.4 & 42.6 & 0.99 & 0.14 & 0.49 \\
\hline $\mathrm{MDA}, \mu \mathrm{mol} / \mathrm{L}$ & 3.62 & 2.28 & 1.84 & 1.77 & 0.10 & $<0.01$ & $<0.01$ \\
\hline GSH-Px, U/mL & 70.8 & 70.4 & 71.1 & 71.0 & 1.57 & 0.86 & 0.93 \\
\hline $\mathrm{SOD}, \mathrm{U} / \mathrm{mL}$ & 65.4 & 65.0 & 82.9 & 83.2 & 3.19 & $<0.01$ & 0.92 \\
\hline $\operatorname{IgA}, \mathrm{mg} / \mathrm{mL}$ & 12.3 & 12.5 & 12.3 & 12.5 & 0.72 & 0.98 & 0.88 \\
\hline $\mathrm{IgG}, \mathrm{mg} / \mathrm{mL}$ & 3.96 & 3.87 & 3.94 & 3.85 & 0.20 & 0.77 & 0.99 \\
\hline $\mathrm{IgM}, \mathrm{mg} / \mathrm{mL}$ & 62.1 & 63.7 & 62.4 & 63.9 & 2.56 & 0.74 & 0.98 \\
\hline IL-1, pg/mL & 38.6 & 38.1 & 38.5 & 37.9 & 0.33 & 0.28 & 0.79 \\
\hline IL-2, pg/mL & 52.2 & 51.1 & 56.1 & 56.8 & 1.92 & 0.05 & 0.65 \\
\hline IL-12, pg/mL & 10.4 & 10.3 & 10.5 & 11.4 & 0.40 & 0.09 & 0.26 \\
\hline TNF- $\alpha, n g / m L$ & 6.96 & 7.25 & 7.61 & 7.74 & 0.11 & $<0.01$ & 0.50 \\
\hline $\mathrm{IFN}-\gamma, \mathrm{ng} / \mathrm{mL}$ & 14.6 & 14.6 & 14.7 & 14.5 & 0.32 & 0.87 & 0.89 \\
\hline
\end{tabular}

${ }^{1} \mathrm{GSH}-\mathrm{Px}=$ glutathione peroxidase $\mathrm{MDA}=$ malondialdehyde; $\mathrm{SOD}=$ superoxide dismutase $\mathrm{TNF}=$ tumor necrosis factor.
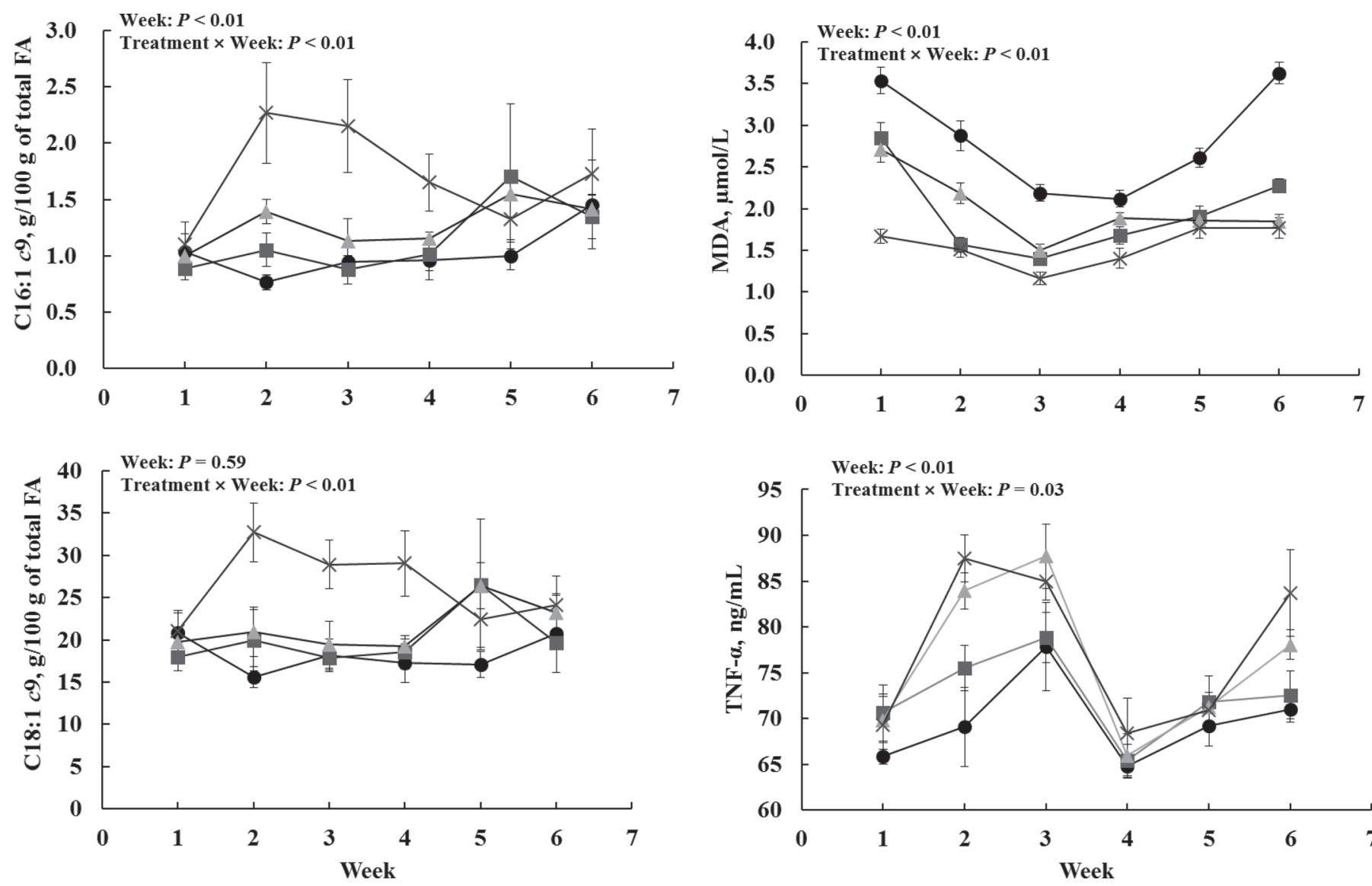

Figure 2. Change in milk fatty acid (FA) profiles including C16:1 cis-9 (c9) and C18:1 cis-9 of lactating cows fed TMR with supplementation of 0 (control, $\bullet), 20(\mathbf{\square}), 30(\mathbf{\Lambda})$, and $40(\times) \mathrm{g} / \mathrm{d}$ of tea saponins. Bars indicate the standard error.

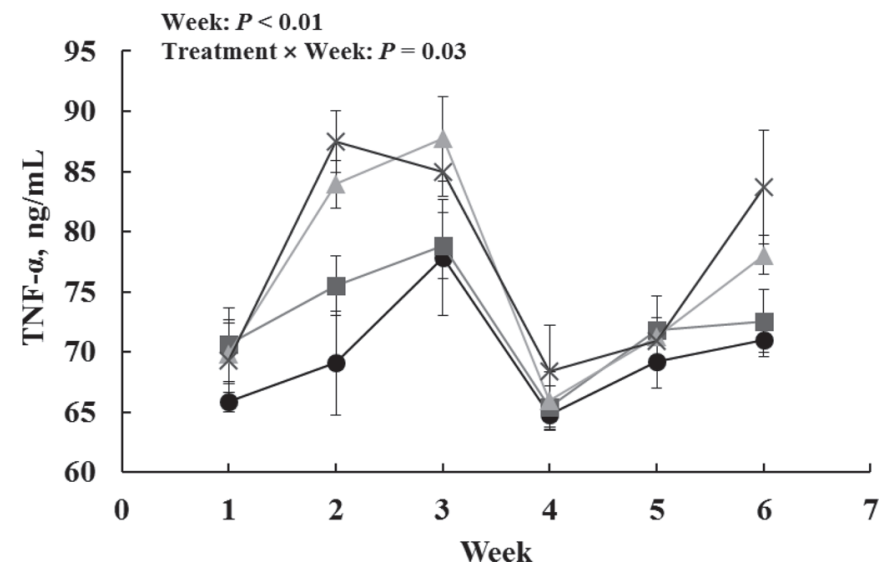

Figure 3. Change in plasma characteristics including malondialdehyde (MDA) and tumor necrosis factor- $\alpha$ (TNF- $\alpha)$ of lactating cows fed TMR with supplementation of 0 (control, $\bullet$ ), $20(\boldsymbol{\square}), 30(\boldsymbol{\Delta})$, and $40(\times) \mathrm{g} / \mathrm{d}$ of tea saponins. Bars indicate the standard error. 
Table 5. Effect of dietary addition of tea saponins for $6 \mathrm{wk}$ on blood cell counts in dairy cows

\begin{tabular}{|c|c|c|c|c|c|c|c|}
\hline Item & \multicolumn{4}{|c|}{ Tea saponins, g/d per head } & SEM & \multicolumn{2}{|c|}{$P$-value } \\
\hline Hematocrit, \% & 27.2 & 20.8 & 20.9 & 21.6 & 2.90 & 0.22 & 0.25 \\
\hline Mean corpuscular hemoglobin, $\mathrm{g} / \mathrm{L}$ & 325 & 326 & 327 & 329 & 2.68 & 0.39 & 0.94 \\
\hline Mean corpuscular volume, fL & 43.6 & 41.9 & 44.2 & 43.2 & 1.59 & 0.88 & 0.82 \\
\hline Red blood cell, $10^{6} / \mu \mathrm{L}$ & 6.22 & 5.01 & 4.85 & 5.01 & 0.70 & 0.25 & 0.35 \\
\hline Basophils, $10^{3} / \mu \mathrm{L}$ & 0.22 & 0.32 & 0.22 & 0.30 & 0.08 & 0.70 & 0.90 \\
\hline Eosinophils, $10^{3} / \mu \mathrm{L}$ & 0.86 & 0.42 & 0.46 & 0.31 & 0.15 & 0.03 & 0.35 \\
\hline Hemoglobin, $g / L$ & 88.4 & 68.0 & 68.2 & 71.2 & 9.78 & 0.26 & 0.25 \\
\hline Platelets, $10^{3} / \mu \mathrm{L}$ & 486 & 431 & 346 & 333 & 78.0 & 0.14 & 0.79 \\
\hline Platelet distribution width, $\%$ & 17.4 & 17.2 & 17.9 & 18.0 & 0.71 & 0.41 & 0.86 \\
\hline Neutrophils, $10^{3} / \mu \mathrm{L}$ & 6.40 & 4.88 & 4.92 & 3.40 & 1.17 & 0.11 & 1.00 \\
\hline
\end{tabular}

supplemented at suitable doses to ruminants (Francis et al., 2002). In the present study, an increased ECM in the cows fed $30 \mathrm{~g} / \mathrm{d}$ TSP resulted in the highest feed efficiency compared with control cows with similar DMI. This phenomenon might be attributed to increased nutrient digestibility because a previous study reported that TSP could improve fiber digestibility (Feng et al., 2013). However, the supplementation of TSP at $40 \mathrm{~g} / \mathrm{d}$ in cows decreased milk and ECM yield, which was accompanied by depression of DMI. The negative effect of saponins on feed intake has been attributed to reduced palatability, intestinal motility, and protein digestibility, as well as the inhibition of nutrient transport (Francis et al., 2002). Thus, we speculate that a similar mechanism leads to decreased DMI in cows supplemented with $40 \mathrm{~g} / \mathrm{d}$ TSP, which was responsible for the quadratic response in this study. A previous study also found that the proper doses of TSP $(3 \mathrm{~g} / \mathrm{d}$ per head, approximately $0.3 \%$ of $\mathrm{DM}$ ) could improve Boer goat growth, whereas an adverse effect on animal production was observed at high doses (Hu et al., 2006). A similar adverse effect on DMI and lactating performance was also found in dairy cows fed a high TSP dose (diet containing $0.52 \%$ TSP on a DM basis). Therefore, the decreased feed efficiency for cows supplemented with $40 \mathrm{~g} / \mathrm{d}$ TSP might be mainly attributed to its negative effects on feed intake and degradation in the rumen (Wang et al., 2012). The tendency for longer-term recovery of ECM production in the $40 \mathrm{~g} / \mathrm{d}$ TSP group was also accompanied by an increase in DMI after $3 \mathrm{wk}$ of feeding. This may indicate that dairy cows need more time to adapt when a relatively higher supplementation dose of TSP is used. Thus, further study should be done to identify the effects of TSP on nutrient digestibility and the effects of extended experimental time on the feeding of TSP on animal performance in lactating dairy cows.

The supplementation of TSP resulted in a quadratic response, shown as lower MUN in cows fed $30 \mathrm{~g} / \mathrm{d}$ TSP. Lower MUN has been shown to be related to lower urinary N excretion (Kauffman and St-Pierre, 2001; Spek et al., 2013). It was also reported that BUN is associated with MUN (Zhu et al., 2013). However, MUN and BUN were not related in the current study, which might be due to the effect of TSP on blood flow. This factor affected $\mathrm{N}$ uptake in mammary glands and kidneys because dietary composition and intake can regulate mammary blood flow (Wang et al., 2016). However, this hypothesis must be verified in further studies. Wina et al. (2005) reviewed several reports that found a negative effect of saponins on rumen ammonia concentration. The lower ruminal ammonia concentration may be explained by a toxic effect of TSP toward protozoa but relatively increased bacterial concentration, leading to greater uptake of ammonia (Wina et al., 2005; Guyader et al., 2017). Thus, the decreased MUN concentration could be attributed to the increased uptake of ammonia by bacteria to generate more microbial protein in the rumen (Herrera-Saldana et al., 1990; Landau et al., 2005; Wang et al., 2014).

\section{Milk Fatty Acid}

To our knowledge, no research has been conducted into the effect of TSP on milk FA composition. In our study, feeding at $40 \mathrm{~g} / \mathrm{d}$ TSP increased UFA, including C16:1 cis-9 and C18:1 cis-9, in milk during the first 4 wk of feeding. The milk cis and trans isomers of 18:1, $18: 2$, and 18:3 are related to rumen microbial biohydrogenation activity (Vlaeminck et al., 2006; Shingfield 
et al., 2013), and thus the greater proportion of C18:1 cis-9 in cows fed $40 \mathrm{~g} / \mathrm{d}$ TSP during the first $4 \mathrm{wk}$ of feeding might be due to its effects on ruminal microbiota and VFA proportions (Hu et al., 2006; Guo et al., 2008; Wang et al., 2012). Increasing the proportion of UFA in milk has been reported to be potentially beneficial for human cardiovascular health (Carroll et al., 2006), which might indicate positive roles of short-term supplementation of TSP in dairy cows. However, the proportion of C16:1 cis-9 and C18:1 cis-9 was similar between the treatments after $4 \mathrm{wk}$ of feeding, which might be another explanation of the potential adaption period with a relatively higher supplementation dose of TSP to dairy cows.

\section{Blood}

Dietary supplementation of TSP linearly decreased the plasma concentration of MDA, increased the concentration of SOD, but had no significant effects on GSH-Px. Supplementation of TSP did not affect the plasma concentrations of GSH-Px and MDA in goats (Zhou et al., 2012), which might due to the length of the experiment or the TSP dosage not being in an appropriate range. Superoxide dismutase plays a role in the conversion of oxygen radicals to peroxides (Bernabucci et al., 2002), whereas MDA is an indicator of oxidative stress because of its function as a lipid peroxidation product (Draper and Hadley, 1990). Blood SOD and MDA are negatively correlated (Wang and Walsh, 2001). Therefore, the higher plasma concentration of SOD and lower MDA in the current study might indicate that the supplementation of TSP reduced oxidative stress in cows. In addition, a previous study found that TSP has antioxidant activity by scavenging free radicals, inhibiting the initiation of a free radical chain reaction, and slowing the automatic oxidation of fat and the formation of peroxide, thereby enhancing antioxidant capacity (Sur et al., 2001).

The supplementation of TSP also increased the plasma concentration of TNF- $\alpha$. Tumor necrosis factor- $\alpha$ is an acute phase protein that is released during inflammatory processes (Gabay and Kushner, 1999). A previous study has also shown that TSP can improve the permeability of capillaries in hypertensive rats (Sagesaka-Mitane et al., 1996). The lower SCC found after supplementation of 20 and $30 \mathrm{~g} / \mathrm{d}$ of TSP confirmed its function in immunomodulatory effects (Bhardwaj et al., 2014). Previous studies also found that milk SCC is related to the antioxidant status of the body (Suriyasathaporn et al., 2006). Therefore, the ability of TSP to reduce milk SCC in this study might be related to its antioxidant and immune functions.
We found no previous studies on the effect of TSP supplementation on the blood cell counts of dairy cows. Eosinophils have been shown to be involved in inflammation; their increased value can reflect some degree of activity in asthmatic patients in both acute and chronic states (Marouf et al., 1999). A linear decrease occurred for both lymphocytes and eosinophils in cows fed TSP compared to the control, indicating the improvement of health status after dairy cows consumed TSP. Changes in lymphocytes and eosinophils were consistent with the plasma immune index and were within the normal range for healthy, mid-lactation Holstein cows (George et al., 2010).

Marcos et al. (2003) reviewed the effects of nutrition on immunity. The increased oxidative and immune status of animal may also be attributed to better nutrient availability and ruminal nutrient degradation after a suitable dose of TSP is consumed. Proto-panaxadiol saponin has been established as enhancing immunity by diminishing the release of inflammatory mediators, such as nitric oxide, and inhibiting the activity of enzymes, such as cyclooxygenase (Yang et al., 2015). Thus, TSP supplementation might have the same effects on antioxidant and immune functions. Therefore, TSP supplementation may improve immunity in dairy cows, which could help to increase performance.

\section{CONCLUSIONS}

This study has shown that an intermediate dose of TSP (20 and $30 \mathrm{~g} / \mathrm{d}$ ) had no significant effect on feed intake, but the supplementation of $40 \mathrm{~g} / \mathrm{d}$ TSP decreased dairy cows' DMI and resulted in lower milk yield. The ECM of cows showed a quadratic response when the supplementation dose of TSP increased after 6 wk of feeding. The ECM of cows fed $40 \mathrm{~g} / \mathrm{d}$ TSP first declined but rose after $3 \mathrm{wk}$ of feeding. The milk UFA in cows fed $40 \mathrm{~g} / \mathrm{d}$ TSP was greater during the first 4 wk of feeding but later tended to be similar to that of cows receiving the other treatments, indicating potential adaption to high doses of TSP supplements in dairy cows. Regardless of dosage, TSP may reduce oxidative stress and improve immunity in cows. In total, the supplementation of TSP at an appropriate dosage is potentially good for the health of dairy cows and can help dairy cows generate more milk UFA with shortterm feeding. The results of this study showed that the supplementation of $30 \mathrm{~g} / \mathrm{d}$ TSP to lactating dairy cows was optimal.

\section{ACKNOWLEDGMENTS}

This research was supported by grants from the Research on Information Perception and Mecha- 
nism of Animal Precision Feeding Management (No. 2016YFDO700201 and No. 2016YFDO700205) and China Postdoctoral Science Foundation (2017M611072). The authors thank the members of the Beijing Key Laboratory for Dairy Cow Nutrition, Beijing University of Agriculture (Beijing, China) for their assistance in the sampling and analysis of the samples. Special thanks go to Geoffrey Zanton from the US Dairy Forage Research Center (Madison, WI) for providing help with manuscript language revision.

\section{REFERENCES}

AOAC (Association of Official Analytical Chemists). 1990. Official Methods of Analysis. 15th ed. AOAC, Arlington, VA.

AOAC International. 2000. Official Methods of Analysis. 17th ed. AOAC International, Arlington, VA.

Bernabucci, U., B. Ronchi, N. Lacetera, and A. Nardone. 2002. Markers of oxidative status in plasma and erythrocytes of transition dairy cows during hot season. J. Dairy Sci. 85:2173-2179.

Bhardwaj, J., N. Chaudhary, H.-J. Seo, M.-Y. Kim, T.-S. Shin, and J.D. Kim. 2014. Immunomodulatory effect of tea saponin in immune T-cells and T-lymphoma cells via regulation of Th1, Th2 immune response and MAPK/ERK2 signaling pathway. Immunopharm. Immunotoxicol. 36:202-210.

Carroll, S. M., E. J. DePeters, and M. Rosenberg. 2006. Efficacy of a novel whey protein gel complex to increase the unsaturated fatty acid composition of bovine milk fat. J. Dairy Sci. 89:640-650.

Delamaire, E., and J. Guinard-Flament. 2006. Increasing milking intervals decreases the mammary blood flow and mammary uptake of nutrients in dairy cows. J. Dairy Sci. 89:3439-3446.

Draper, H. H., and M. Hadley. 1990. Malondialdehyde determination as index of lipid peroxidation. Methods Enzymol. 186:421-431.

Feng, Y., J. Jiang, L. Zhu, L. Yue, J. Zhang, and S. Han. 2013. Effects of tea saponin on glucan conversion and bonding behaviour of cellulolytic enzymes during enzymatic hydrolysis of corncob residue with high lignin content. Biotechnol. Biofuels 6:161.

Francis, G., Z. Kerem, H. P. Makkar, and K. Becker. 2002. The biological action of saponins in animal systems: A review. Br. J. Nutr. 88:587-605.

Gabay, C., and I. Kushner. 1999. Acute-phase proteins and other systemic responses to inflammation. N. Engl. J. Med. 340:448-454.

George, J. W., J. Snipes, and V. M. Lane. 2010. Comparison of bovine hematology reference intervals from 1957 to 2006. Vet. Clin. Pathol. 39:138-148.

Guo, Y. Q., J. X. Liu, Y. Lu, W. Y. Zhu, S. E. Denman, and C. S. McSweeney. 2008. Effect of tea saponin on methanogenesis, microbial community structure and expression of $m c r A$ gene, in cultures of rumen microorganisms. Lett. Appl. Microbiol. 47:421-426.

Guyader, J., M. Eugène, M. Doreau, D. Morgavi, C. Gérard, C. Loncke, and C. Martin. 2015. Nitrate but not tea saponin feed additives decreased enteric methane emissions in nonlactating cows. J. Anim. Sci. 93:5367-5377.

Guyader, J., M. Eugène, M. Doreau, D. Morgavi, C. Gérard, and C. Martin. 2017. Tea saponin reduced methanogenesis in vitro but increased methane yield in lactating dairy cows. J. Dairy Sci. 100:1845-1855.

Herrera-Saldana, R., R. Gomez-Alarcon, M. Torabi, and J. Huber. 1990. Influence of synchronizing protein and starch degradation in the rumen on nutrient utilization and microbial protein synthesis. J. Dairy Sci. $73: 142-148$.

Hu, W., J. Liu, Y. Wu, Y. Guo, and J. Ye. 2006. Effects of tea saponins on in vitro ruminal fermentation and growth performance in growing Boer goat. Arch. Anim. Nutr. 60:89-97.

Kauffman, A. J., and N. R. St-Pierre. 2001. The relationship of milk urea nitrogen to urine nitrogen excretion in Holstein and Jersey cows. J. Dairy Sci. 84:2284-2294.
Landau, S., D. Kababya, N. Silanikove, R. Nitsan, L. Lifshitz, H. Baram, I. Bruckental, and S. Mabjeesh. 2005. The ratio between dietary rumen degradable organic matter and crude protein may affect milk yield and composition in dairy sheep. Small Rumin. Res. 58:115-122.

Li, E., N. Sun, J. X. Zhao, Y. G. Sun, J. G. Huang, H. M. Lei, J. H. Guo, Y. L. Hu, W. K. Wang, and H. Q. Li. 2015. In vitro evaluation of antiviral activity of tea seed saponins against porcine reproductive and respiratory syndrome virus. Antivir. Ther. 20:743-752.

Li, W., and W. Powers. 2012. Effects of saponin extracts on air emissions from steers. J. Anim. Sci. 90:4001-4013.

Mann, G. V. 1961. A method for measurement of cholesterol in blood serum. Clin. Chem. 7:275-284.

Mao, H. L., J. K. Wang, Y. Y. Zhou, and J. X. Liu. 2010. Effects of addition of tea saponins and soybean oil on methane production, fermentation and microbial population in the rumen of growing lambs. Livest. Sci. 129:56-62.

Marcos, A., E. Nova, and A. Montero. 2003. Changes in the immune system are conditioned by nutrition. Eur. J. Clin. Nutr. 57:S66S69.

Marouf, R., M. Khadadah, B. Onadeko, H. Mustafa, A. Khamis, C. Ezeamuzie, and T. Sugathan. 1999. The effect of corticosteroid therapy on blood eosinophils and eosinophilic cationic protein in patients with acute and chronic asthma. J. Asthma 36:555-564.

MOA (Ministry of Agriculture of P.R. China). 2004. Feeding Standard of Dairy Cattle (NY/T 34-2004). MOA, Beijing, China.

Orth, R. 1992. Sample day and lactation report, DHIA 200. Fact Sheet A-2. Mid-States Dairy Records Processing Center (DRPC), Ames, IA.

Pegolo, S., A. Cecchinato, J. Casellas, G. Conte, M. Mele, S. Schiavon, and G. Bittante. 2016. Genetic and environmental relationships of detailed milk fatty acids profile determined by gas chromatography in Brown Swiss cows. J. Dairy Sci. 99:1315-1330.

Rahmatullah, M., and T. Boyde. 1980. Improvements in the determination of urea using diacetyl monoxime; methods with and without deproteinisation. Clin. Chim. Acta 107:3-9.

Ramírez-Restrepo, C. A., C. Tan, C. J. O'Neill, N. López-Villalobos, J. Padmanabha, J. Wang, and C. S. McSweeney. 2016. Methane production, fermentation characteristics, and microbial profiles in the rumen of tropical cattle fed tea seed saponin supplementation. Anim. Feed Sci. Technol. 216:58-67.

Sagesaka-Mitane, Y., T. Sugiura, Y. Miwa, K. Yamaguchi, and K. Kyuki. 1996. Effect of tea-leaf saponin on blood pressure of spontaneously hypertensive rats. Yakugaku Zasshi 116:388-395.

Shingfield, K. J., M. Bonnet, and N. D. Scollan. 2013. Recent developments in altering the fatty acid composition of ruminant-derived foods. Animal 7:132-162.

Spek, J., J. Dijkstra, G. Van Duinkerken, and A. Bannink. 2013. A review of factors influencing milk urea concentration and its relationship with urinary urea excretion in lactating dairy cattle. J. Agric. Sci. 151:407-423.

Sur, P., T. Chaudhuri, J. Vedasiromoni, A. Gomes, and D. Ganguly. 2001. Antiinflammatory and antioxidant property of saponins of tea [Camellia sinensis (L) O. Kuntze] root extract. Phytother. Res. 15:174-176.

Suriyasathaporn, W., U. Vinitketkumnuen, T. Chewonarin, S. Boonyayatra, K. Kreausukon, and Y. Schukken. 2006. Higher somatic cell counts resulted in higher malondialdehyde concentrations in raw cows' milk. Int. Dairy J. 16:1088-1091.

Thomas, L. 1998. Clinical Laboratory Diagnostics. 1st ed. TH-Book Verlagsgesellschaft, Frankfurt/Main, Germany.

Van Soest, P. J., J. B. Robertson, and B. A. Lewis. 1991. Methods for dietary fiber, neutral detergent fiber, and nonstarch polysaccharides in relation to animal nutrition. J. Dairy Sci. 74:3583-3597.

Vlaeminck, B., V. Fievez, A. Cabrita, A. Fonseca, and R. Dewhurst. 2006. Factors affecting odd- and branched-chain fatty acids in milk: A review. Anim. Feed Sci. Technol. 131:389-417.

Wanapat, M., P. Kongmun, O. Poungchompu, A. Cherdthong, P. Khejornsart, R. Pilajun, and S. Kaenpakdee. 2012. Effects of plants 
containing secondary compounds and plant oils on rumen fermentation and ecology. Trop. Anim. Health Prod. 44:399-405.

Wang, B., S. Mao, H. Yang, Y. Wu, J. Wang, S. Li, Z. Shen, and J. Liu. 2014. Effects of alfalfa and cereal straw as a forage source on nutrient digestibility and lactation performance in lactating dairy cows. J. Dairy Sci. 97:7706-7715.

Wang, B., H. Z. Sun, N. N. Xu, K. J. Zhu, and J. X. Liu. 2016. Amino acid utilization of lactating dairy cows when diets are changed from an alfalfa-based diet to cereal straw-based diets. Anim. Feed Sci. Technol. 217:56-66.

Wang, J. K., J. A. Ye, and J. X. Liu. 2012. Effects of tea saponins on rumen microbiota, rumen fermentation, methane production and growth performance - A review. Trop. Anim. Health Prod. 44:697-706.

Wang, Y., and S. Walsh. 2001. Increased superoxide generation is associated with decreased superoxide dismutase activity and mRNA expression in placental trophoblast cells in pre-eclampsia. Placenta $22: 206-212$.

Wina, E., S. Muetzel, and K. Becker. 2005. The impact of saponins or saponin-containing plant materials on ruminant production- $\mathrm{A}$ review. J. Agric. Food Chem. 53:8093-8105.
Yang, Y., X. Li, L. Zhang, L. Liu, G. Jing, and H. Cai. 2015. Ginsenoside Rg1 suppressed inflammation and neuron apoptosis by activating PPAR $\gamma / \mathrm{HO}-1$ in hippocampus in rat model of cerebral ischemia-reperfusion injury. Int. J. Clin. Exp. Pathol. 8:2484-2494.

Zhang, X. Y., Y. L. Tan, L. Y. Cao, G. Y. Wu, Q. Xu, Y. Shen, and D. F. Zhou. 2006. Antioxidant enzymes and lipid peroxidation in different forms of schizophrenia treated with typical and atypical antipsychotics. Schizophr. Res. 81:291-300.

Zhou, C., W. Xiao, Z. Tan, A. Salem, M. Geng, S. Tang, M. Wang, X. Han, and J. Kang. 2012. Effects of dietary supplementation of tea saponins (Ilex kudingcha CJ Tseng) on ruminal fermentation, digestibility and plasma antioxidant parameters in goats. Anim. Feed Sci. Technol. 176:163-169.

Zhu, W., Y. Fu, B. Wang, C. Wang, J. Ye, Y. Wu, and J.-X. Liu. 2013. Effects of dietary forage sources on rumen microbial protein synthesis and milk performance in early lactating dairy cows. J. Dairy Sci. 96:1727-1734. 